\title{
Oxygen and sulfur isotopic compositions of quartz, barite and sulfide minerals from the Sambo Pb-Zn-barite ore deposits, South Korea
}

\author{
KYU HAN KIM ${ }^{1}$, YoshIHIKo MIZUTANI ${ }^{2}$ and HI SOO MOON ${ }^{3}$ \\ ${ }^{1}$ Department of Science Education, Ewha Womans University, Seoul, Korea 120-750 \\ ${ }^{2}$ Department of Earth Science, Toyama University, Toyama 930, Japan \\ ${ }^{3}$ Department of Geology, Yonsei University, Seoul, Korea 120-749
}

(Received October 28, 1991; Accepted May 15, 1995)

\begin{abstract}
Oxygen and sulfur isotopic compositions of sulfate, quartz and sulfide minerals from the veins of the Sambo lead-zinc-barite ore deposits have been measured to study their depositional conditions and evolution of ore fluids.

The results are as follows: (1) The $\delta^{34} \mathrm{~S}$ values of sulfides vary from -3.9 to $-13.5 \%$ and those of sulfates from +15.7 to $+17.2 \%$. Isotopic temperatures from barite-sphalerite and barite-galena pairs were $210-290^{\circ} \mathrm{C}$, in fairly good agreement with the homogenization temperatures of fluid inclusions in the stage II quartz. At relatively low temperatures $\left(210-290^{\circ} \mathrm{C}\right)$, isotopic equilibria were attained between sulfate and sulfide minerals in the Sambo ore deposits. (2) Barites have homogeneous $\delta^{34} \mathrm{~S}$ and $\delta^{18} \mathrm{O}$ values of +15.7 to $+17.2 \%$ and +2.4 to $+3.9 \%$, respectively.

Calculated $\delta^{18} \mathrm{O}$ values of ore fluids in equilibrium with barite and quartz vary from -2.1 to $+0.9 \%$ and -4.2 to $-1.3 \%$, respectively, suggesting a contribution of ${ }^{18} \mathrm{O}$ depleted meteoric water to ore fluids of the Sambo deposits.
\end{abstract}

\section{INTRODUCTION}

The Sambo Pb-Zn-barite mineral deposits are in the Precambrian Kyonggi metamorphic belt of the midwestern coast of Korean peninsula (Fig. 1). From 1983 to 1990 , the mine produced 2200 metric tons/y of barite ores with $15-20 \mathrm{wt} \% \mathrm{Ba}$, 3000 metric $\mathrm{t} / \mathrm{y}$ of lead ores with $15-20 \mathrm{wt} \% \mathrm{~Pb}$, and 9000 metric $t / y$ of zinc ores with $4-5 \mathrm{wt} \%$ Zn, respectively. Park and Park (1980) and Jwa (1989) have studied the geology and fluid inclusion, but little is known about depositional conditions of ore minerals (So et al., 1984). This paper presents the oxygen and sulfur isotope data for ore and gangue minerals including sulfides, sulfate and quartz in the Sambo deposits. These isotopic data would constrain the source of ore fluids, attainment of sulfate-sulfide mineral equilibria and depositional conditions of the ores. Our purpose is to interpret the evolution of ore fluids and to determine the conditions of ore formation under which the sulfide and sulfate minerals were deposited in the hydrothermal system.

\section{GEOLOGY}

The geology of the Sambo mine area has been summarized by Park and Park (1980), So et al. (1984) and Jwa (1989) as shown on the simplified geologic map (Fig. 1).

The host rocks of the Sambo ore veins are Precambrian metamorphic rocks consisting mainly of mica schist and biotite gneiss. Sulfate- and sulfide-bearing quartz veins were emplaced along the NW fissures of the metamorphic rocks which have trends of $\mathrm{N} 20$ to $40 \mathrm{E}$ and dips of 30 to $50 \mathrm{SE}$. Granodiorite and granite of Jurassic age intruded into the metamorphic rocks in the northeastern and northwestern parts of the mine. Radiometric K-Ar age determination for biotite from a biotite granite stock located about $2 \mathrm{~km}$ northwest of the Sambo mine gave an age of $177.3 \pm 3.6 \mathrm{~m} . \mathrm{y}$, and a 


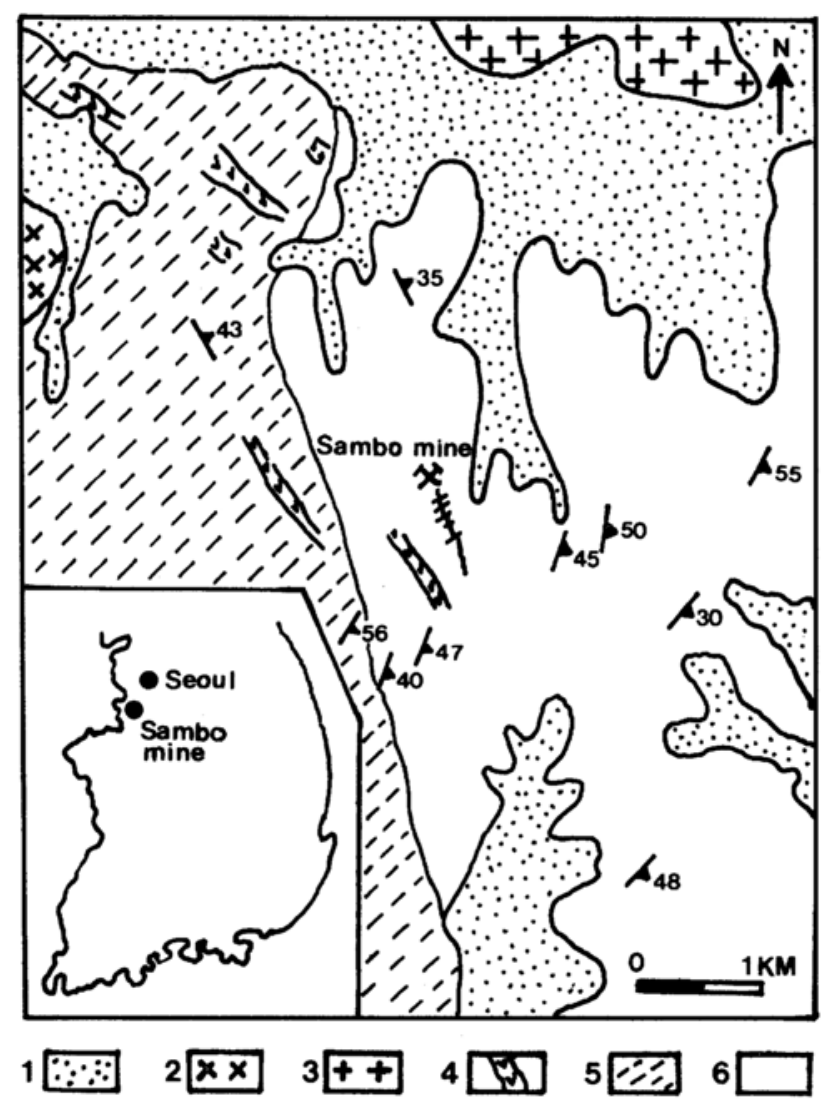

Fig. 1. Geologic map of the Sambo Pb-Zn-barite ore deposits. 1, Alluvium; 2, Biotite granite; 3, Granodiorite; 4, Felsic dike; 5, Mica schist; 6, Biotite gneiss (Modified from Jwa, 1989).

granodiorite in the northwestern part of the mine was dated as $163.6 \pm 3.3 \mathrm{~m}$.y (So et al., 1984). So et al. concluded that the $\mathrm{Pb}-\mathrm{Zn}$ mineralization was associated with the intrusion of those plutonic rocks.

Two subparallel quartz veins with NW and NS directions extend $2 \mathrm{~km}$ along the fissures in the biotite gneiss (Fig. 2). The NS vein consists mainly of milky white barren quartz. Productive quartz veins with 0.5 to $15 \mathrm{~m}$ ( 5 to $6 \mathrm{~m}$ on an average) width are named Northern orebody, Southern orebody and New southern ore body which is currently exploited along the NW vein. The veins were displaced by several post mineralization step faultings with E-W and NE directions as shown in Fig. 2. Ore veins contain mainly sphalerite, galena, chalcopyrite and barite. Gangue minerals are quartz and small amounts of calcite, fluorite and rhodochrosite. So et al. (1984) reported detailed vein mineralogy and divided the mineralization at Sambo into three distinct stages on the basis of ore texture, tectonic fracturing and brecciation events.

In the present study we divide the mineralization events into the following three stages: (I) Fracturing and wall rock alteration stage, (II) barite-sulfide coprecipitation stage, and (III) the latest barren quartz vein stage. This classification is different from that of So et al. (1984) in mineral assemblage of each stage.

Stage I: Wall rock alteration develops weakly in the vicinity of quartz veins. Alteration minerals, such as chlorite, sericite and quartz, are common in this stage. The wall rock alteration is characterized by silicification, chloritization and sericitization accompanied by fracturing events. 


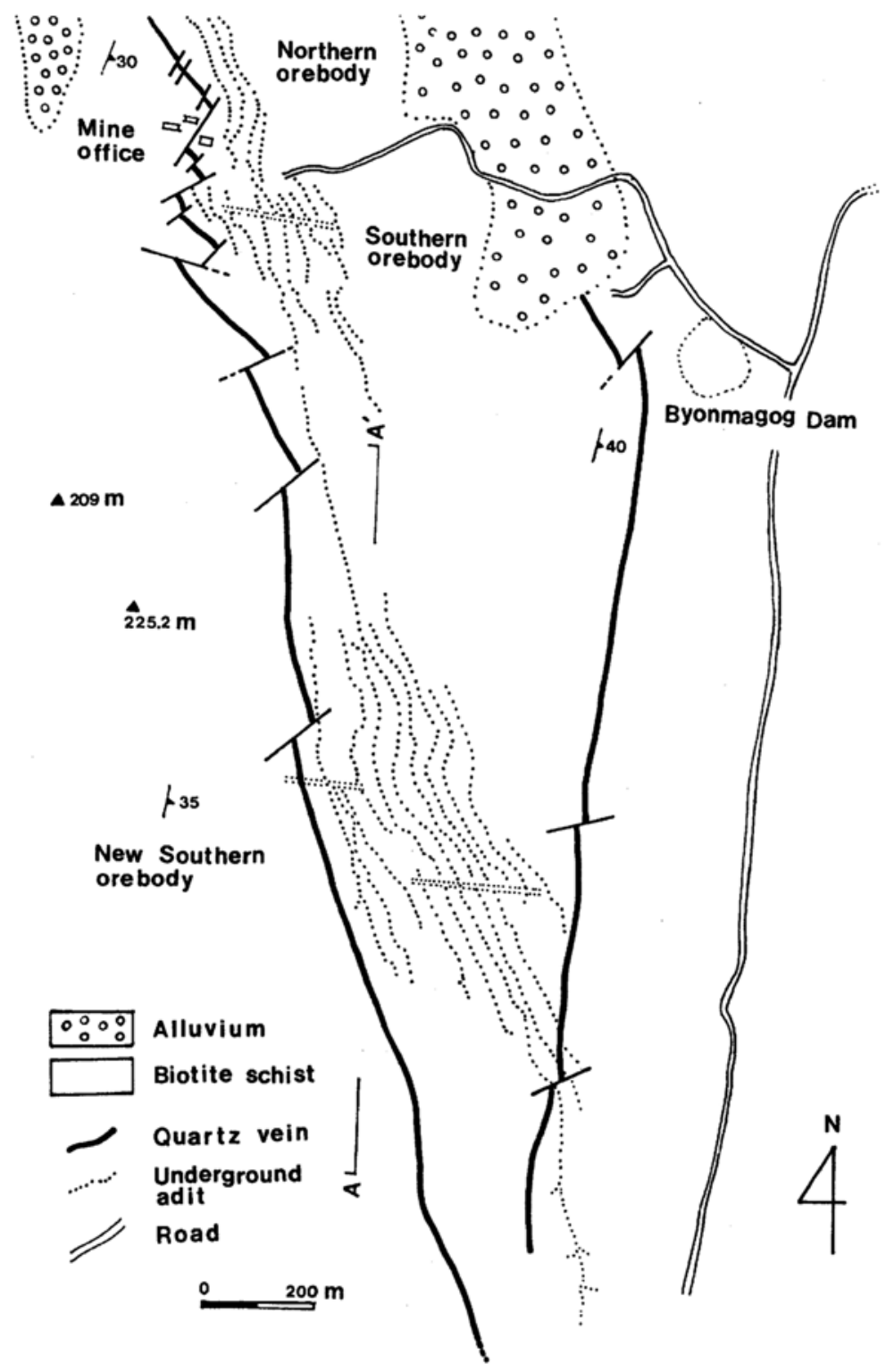

Fig. 2. Vein map of the Sambo mineral deposits.

Grey quartz vein containing fragments of schist has a small amount of pyrite.

Stage II: Abundant barite-sphalerite-galena minerals are associated with white and pinkish quartz veins. Stage II veins cut stage I veins (Fig. 4(a)). Stage II veins are subgrouped into several mineral zones that surround vugs, such as quartzsphalerite-chalcopyrite, quartz-sphalerite-barite and barite-galena mineral assemblages. Small amounts of calcite, chalcedonic quartz, rhodochrosite and fluorite occur in the druse of quartz veins. Mineral paragenesis is shown in Fig. 3. Barite coexists abundantly with sulfide minerals in the stage II veins as shown in Figs. 4(a) and (b). Quartzsphalerite-barite-galena mineral assemblage is common in the veins. Quartz-sphalerite-galenachalcopyrite assemblage rarely occurs at the level9 of the New southern orebody. Galena tends to 


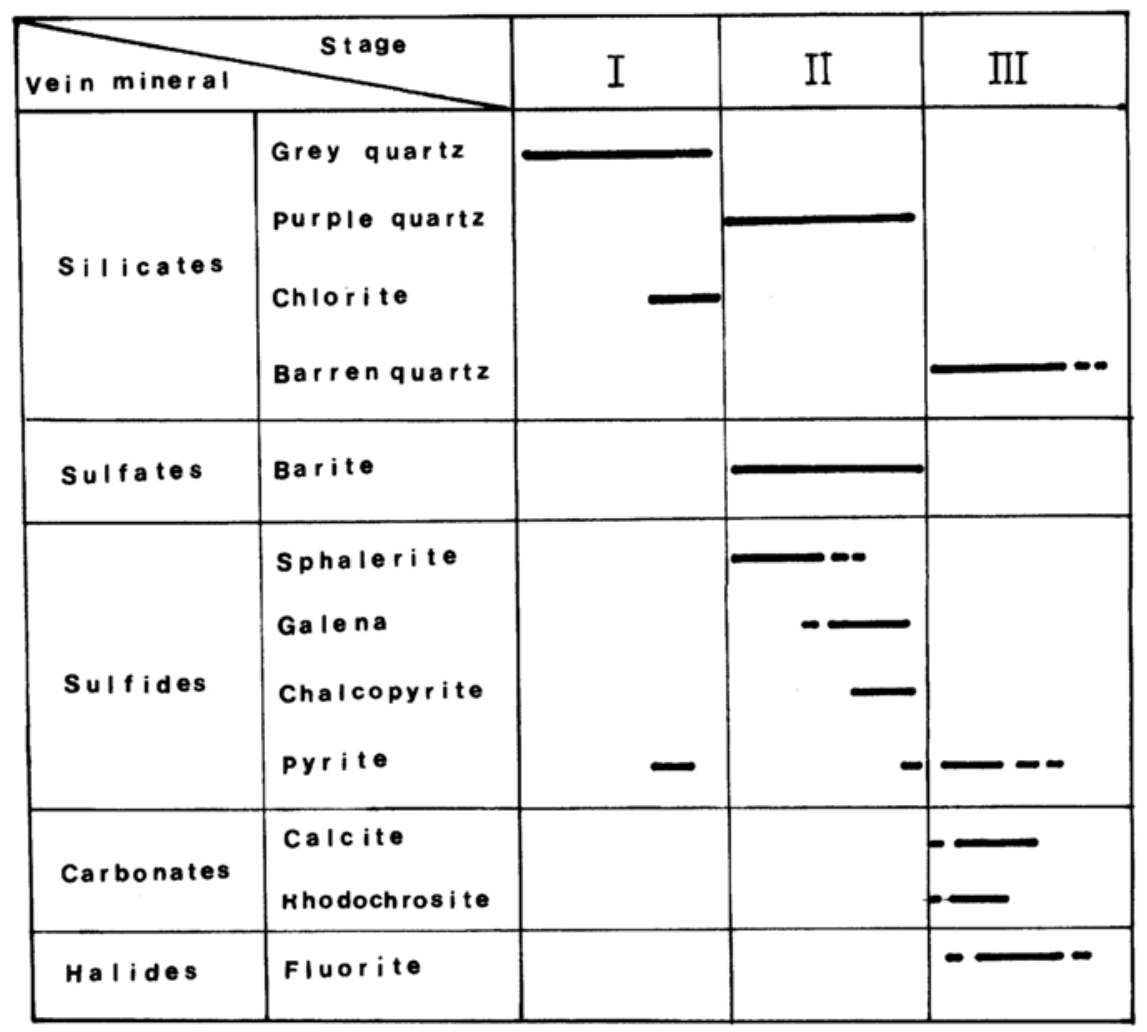

Fig. 3. Mineral paragenesis of the Sambo Pb-Zn-barite ore deposits.

increase in amount with depth. In the marginal part of the veins galena occurs free from sphalerite.

Generally, quartz-bearing barite veins have Ferich sphalerite, while Fe-poor sphalerite is observed in the barite-rich quartz veins. Quartz-barite veins which lack sulfide minerals crop out in the level-5 of the New southern orebody. Figure 4(a) shows massive barite ore. Barite intergrown with sulfide minerals are shown in Fig. 4(b). The equivocal mineral paragenesis between coexisting barite and sulfide minerals strongly suggests that they were coprecipitated in Stage II (Fig. 4(b)).

Stage III: Veins and veinlets of quartz and calcite of the latest stage containing a small amount of euhedral pyrite cut across the stage I and stage II veins. No ore minerals such as barite, sphalerite and galena occur in the veins.

Jwa (1989) interpreted differently the mineral paragenesis at Sambo, emphasizing that barite was precipitated in a different depositional stage from sulfide. The barites collected from stage II ores in this study, however, apparently coexisted and possibly coprecipitated with sulfides, as shown in Figs. 4(a) and (b).

\section{SAMPle Collection and Isotope ANALYSIS}

Sulfide and sulfate mineral samples were collected from the stage II veins of different levels in the New southern orebody as shown in Fig. 5. Eight quartz samples were taken from veins of the stage I, II and III. For sulfur isotopic analysis, sulfide and sulfate minerals were converted to $\mathrm{Ag}_{2} \mathrm{~S}$ (Rafter, 1957) before combustion at $1000^{\circ} \mathrm{C}$ with $\mathrm{Cu}_{2} \mathrm{O}$ to yield $\mathrm{SO}_{2}$ (Robinson and Kusakabe, 1975). Oxygen isotope analysis of sulfates was performed by the graphite reduction method (Rafter and Mizutani, 1967; Mizutani, 1971). Oxygen was extracted from quartz by the $\mathrm{BrF}_{5}$ technique (Clayton and Mayeda, 1963). Sulfur and 

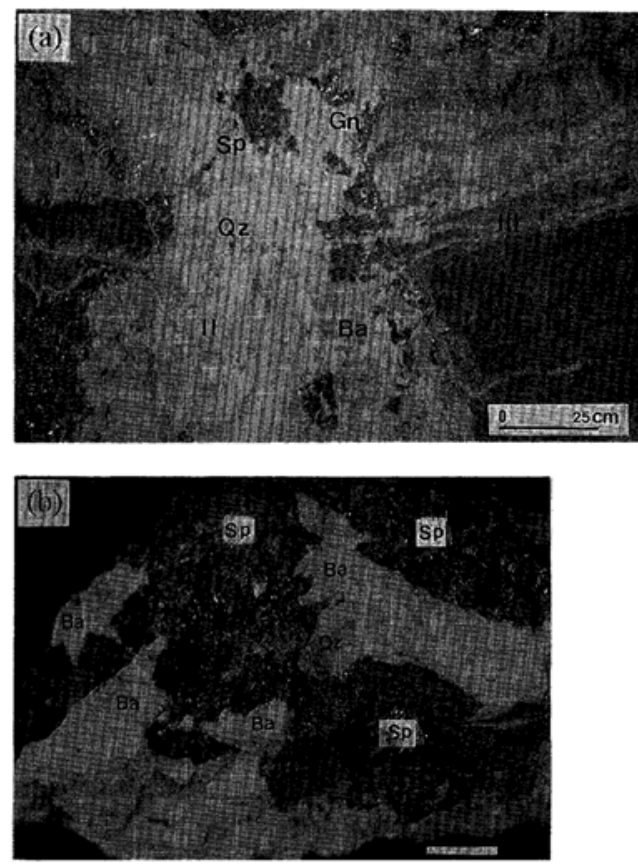

Fig. 4. (a) Sulfide-sulfate bearing quartz vein of stage II. Stage I vein is cut by stage II vein at level-6 of the New southern orebody. Galena is precipitated at the margin of the stage II vein. (b) Coexisting and coprecipitated sphalerite and barite in the New southern orebody $(-3 L)$. Barite crystals intergrow with the sulfide minerals. Barite crystals intrude to sphalerite and small barite inclusions are remained in the sphalerite. The length of the scale bar is $1 \mathrm{~cm}$. oxygen isotope ratios were measured with a double-collector mass spectrometer. The results are expressed in a $\delta$-notation relative to the SMOW standard for oxygen and Canyon Diablo troilite (CDT) standard for sulfur. The standard error is $\pm 0.2 \%$ for oxygen and $\pm 0.2 \%$ for sulfur, respectively.

\section{RESUltS AND DISCUSSION}

\section{Sulfur isotopes}

Analytical results are listed in Table 1. Sulfur isotope ratios of barites vary from +15.7 to $+17.2 \%$, Those of sphalerites range from -3.9 to $-8.9 \%$ and galenas -9.5 to $-13.5 \%$. The $\delta^{34} \mathrm{~S}$ values for sulfides are fairly uniform throughout the paragenesis. No systematic vertical variation of sulfur isotope values was found in the New southern orebody. The sulfur isotope ratios of sulfide minerals are lower than the average sulfur isotope ratio of hydrothermal sulfide minerals $(+4.2 \%)$ from various base metal ore deposits in South Korea (Kim and Nakai, 1980).

Textures of the barite-bearing assemblages indicate that barite, sphalerite and galena were coprecipitated, as shown in Figs. 4(a) and (b). These assemblages should be appropriate samples from which sulfur isotopic thermometry. The

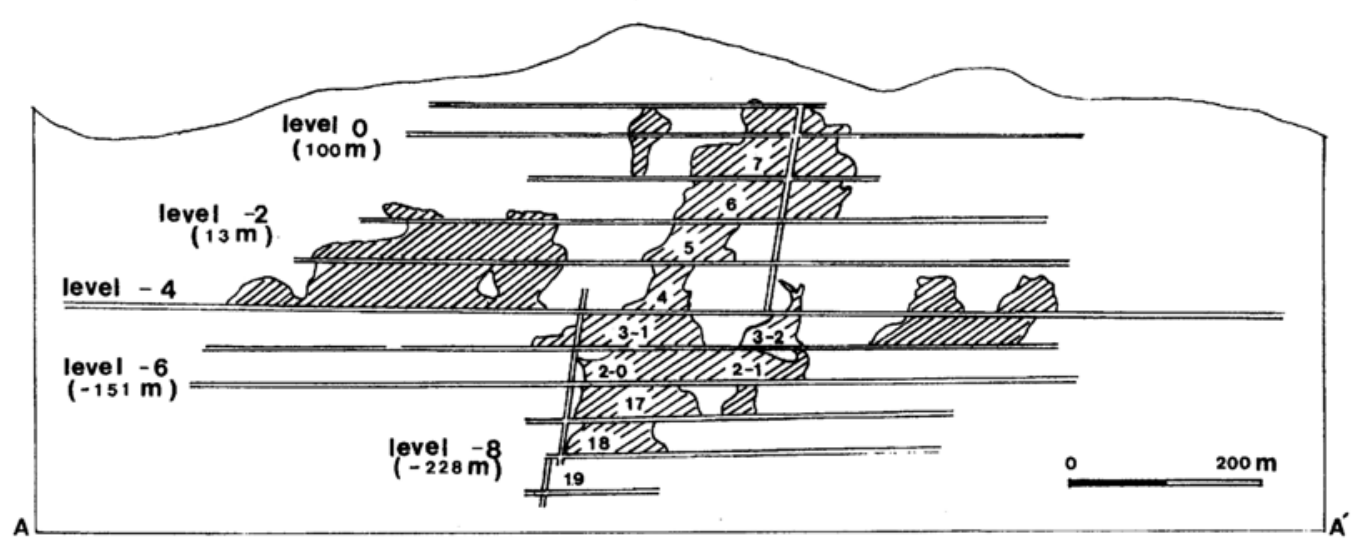

Fig. 5. Longitudinal section $\left(A-A^{\prime}\right.$ in Fig. 2) projected on the plane of the New southern orebody showing sample localities. Hatched area shows the sulfide-sulfate orebodies. Numericals in the hatched area indicate sampling numbers. 


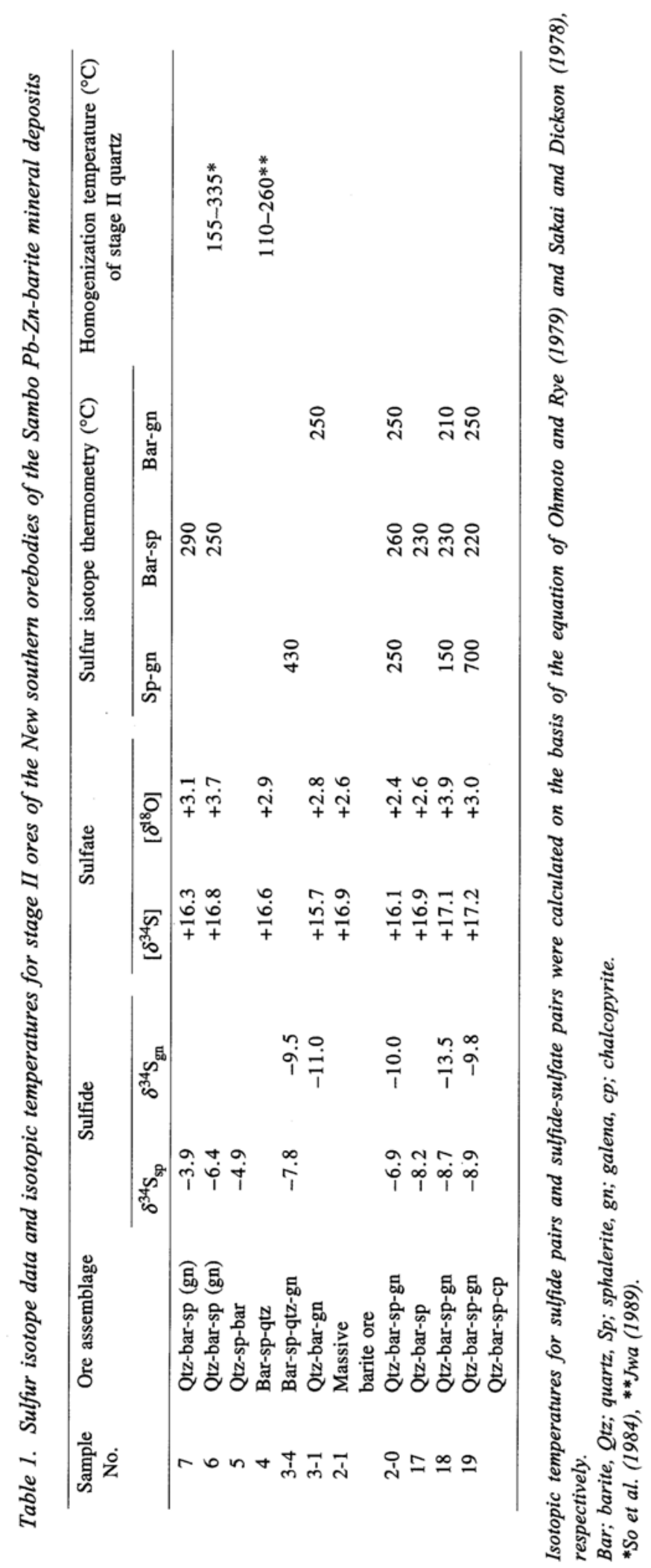




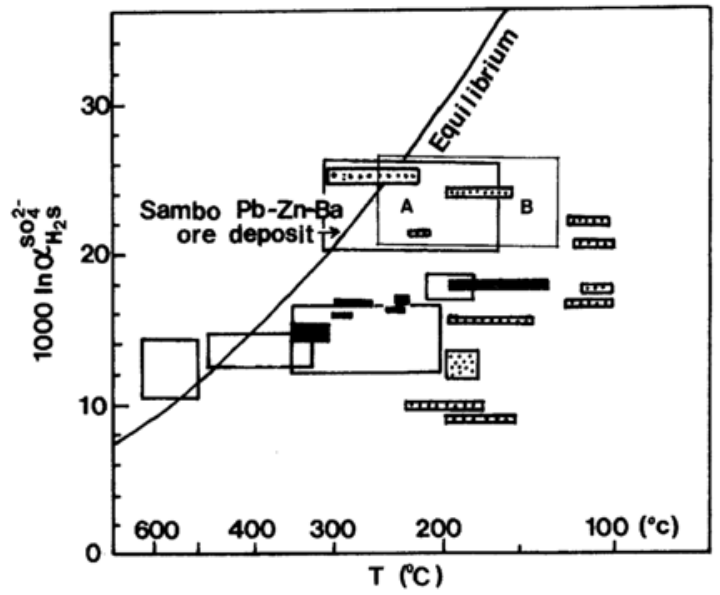

Fig. 6. Relationship between the sulfate-sulfide isotopic fractionation and depositional temperatures using homogenization temperatures of fluid inclusions (Modified from Ohmoto and Lasaga, 1982). Data for homogenization temperatures of fluid inclusions from the Sambo ore deposits are taken from So et al., 1984 (Box A) and Jwa, 1989 (Box B). Open and solid square symbols indicate the vein and Mississippi valley types, and the Kuroko type deposits. Dotted boxes show the porphyry type deposits.

sulfur isotopic temperatures from the baritesphalerite, barite-galena and sphalerite-galena pairs from the New southern orebody are listed in Table 1. They are $220-290^{\circ} \mathrm{C}$ for the barite-sphalerite pairs, $210-250^{\circ} \mathrm{C}$ for baritegalena pairs and 150 to $700^{\circ} \mathrm{C}$ for sphalerite-galena pairs. The sulfatesulfide isotopic temperatures for the stage II veins $\left(210-290^{\circ} \mathrm{C}\right)$ are consistent with homogenization temperatures of fluid inclusions in quartz for the same stage ranging from $155-335^{\circ} \mathrm{C}$ (av. $250^{\circ} \mathrm{C}$ ) reported by So et al. (1984) and 110-260 (av. $230^{\circ} \mathrm{C}$ ) by Jwa (1989).

The sphalerite-galena pairs, however, yielded a rather wide range of isotopic temperatures compared to the barite-sulfide pairs. The isotopic temperatures estimated from the sphalerite-galena pairs are less reliable than those from the baritesulfide pairs if the analytical error is taken into account, since the sphalerite-galena fractionation is not temperature-sensitive. In addition, some galena coexisted with sphalerite are not in equi- librium as shown in sample No. 19 of Table 1.

The agreement of the isotopic temperatures with the fluid inclusion homogenization temperatures suggests that isotopic equilibria were attained at the temperature range from 210 to $290^{\circ} \mathrm{C}$ among the sulfate and sulfide minerals in the stage II fluids, and that the ore minerals were precipitated at relatively shallow depths because the pressure correction would have shifted the homogenization temperatures to higher values.

Ohmoto and Lasaga (1982) found that at temperatures below $350^{\circ} \mathrm{C}$ almost all sulfate-sulfide mineral pairs were formed from solutions in which the isotopic fractionation between aqueous sulfate and sulfide was much smaller than the equilibrium values at the depositional temperatures. Examples are illustrated in Fig. 6. This discrepancy was explained by mixing of a sulfide-rich solution with a sulfate-rich solution at the depositional site without equilibration (Ohmoto and Lasaga, 1982). Isotope data for sulfate-sulfide pairs from the New southern orebody of the Sambo $\mathrm{Pb}-\mathrm{Zn}$-barite ore deposit also fall in a wide range of temperatures from $335^{\circ} \mathrm{C}$ (near equilibrium line) to $110^{\circ} \mathrm{C}$, apart from the equilibrium fractionation curve (Fig. 6). It can be explained by the difference in mixing ratio between sulfide and sulfate solutions at depositional site, and/or the increasing influx of meteoric water toward later stages of ore precipitation.

\section{Oxygen isotopes}

Oxygen isotope compositions of quartz and barite from the Sambo ore deposits are given in Table 2. Nine barite samples have a very narrow range of $\delta^{18} \mathrm{O}$ values from +2.4 to $+3.9 \%$. Figure 7 shows a plot of $\delta^{34} \mathrm{~S}$ versus $\delta^{18} \mathrm{O}$ of barites from different sources. The Sambo barites are characterized by a considerable depletion in $\delta^{34} \mathrm{~S}$ and $\delta^{18} \mathrm{O}$ relative to barites from the Kuroko deposits of Japan and bedded barite deposits of Appalachian Mountain, USA, where sedimentary sulfate of sea water origin was reprecipitated. It is likely that sulfur of Sambo barites is of magmatic origin but not of coeval sea water sulfate. The $\delta^{18} \mathrm{O}$ and $\delta^{34} \mathrm{~S}$ values of barites from Sambo are rather close 
Table 2. Oxygen isotopic composition of the stage II barite and quartz from the New Southern orebodies of the Sambo Pb-Zn-barite ore deposits

\begin{tabular}{|c|c|c|c|c|c|c|}
\hline \multirow{2}{*}{$\begin{array}{l}\text { Sample } \\
\text { No. }\end{array}$} & \multicolumn{2}{|c|}{$\delta^{18} \mathrm{O}$ of mineral (\%o) } & \multirow{2}{*}{$\begin{array}{l}\text { Sulfur isotope } \\
\text { temperature }\left({ }^{\circ} \mathrm{C}\right)\end{array}$} & \multicolumn{2}{|c|}{$\delta^{18} \mathrm{O}$ of fluid (\%o) } & \multirow{2}{*}{$\begin{array}{c}\text { Mineral } \\
\text { assemblage }\end{array}$} \\
\hline & Barite & Quartz & & Barite & Quartz & \\
\hline 7 & 3.1 & $5.5^{*}$ & 290 & 0.9 & -1.7 & Qtz-bar-sp (gn) \\
\hline 6 & 3.7 & - & 250 & 0.0 & - & ditto \\
\hline 5 & - & 7.5 & 250 & - & -1.3 & Qtz-sp-bar \\
\hline 4 & 2.9 & $4.6^{* * * *}$ & 250 & -0.8 & -4.2 & Bar-sp-qtz \\
\hline $3-1$ & 2.8 & 6.9 & 250 & -0.9 & -2.0 & Qtz-bar-gn \\
\hline $2-1$ & 2.6 & - & 250 & -1.1 & - & Bar \\
\hline $2-0$ & 2.4 & 6.2 & 260 & -0.6 & -2.2 & Qtz-bar-sp-gn \\
\hline 17 & 2.6 & $8.6^{* *}$ & 230 & -2.0 & -1.3 & Qtz-bar-sp \\
\hline 18 & 3.9 & $6.9^{* * *}$ & 230 & -0.7 & -3.0 & Qtz-bar-sp-gn \\
\hline 19 & 3.0 & 7.4 & 230 & -2.1 & -3.0 & Qtz-bar-sp-gn-cp \\
\hline
\end{tabular}

The $\delta^{18} O$ values of fluids were calculated on the basis of fractionation factors by Matsuhisa et al. (1979) for quartz-water and Kusakabe and Robinson (1977) for barite-water system, respectively.

*** Stage I, ***stage III.

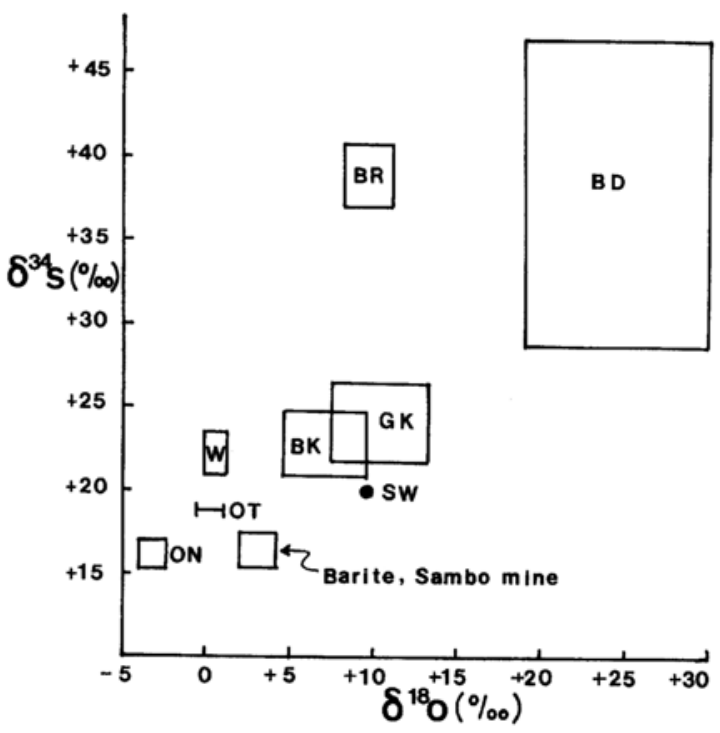

Fig. 7. $\delta^{34} S$ vs $\delta^{18} O$ plot for sulfate minerals. $B K$ and GK: Barite and gypsum from the Kuroko ore, Japan (Sakai et al., 1970). BR: Barite of Rosebery, Tasmania (Solomon et al., 1969). BD: Barite from bedded barite deposits, Appalachian mountains (Nuelle and Shelton, 1986). SW: Sea water sulfate (Thode et al., 1961 and Longinelli and Craig, 1967). W: Geothermal brine, Wairakei New Zealand (Rafter and Mizutani, 1967). OT: Geothermal brine, Ohtake, Japan (Mizutani, 1972). ON: Geothermal brine, Ohnuma, Japan (Sakai, 1977). to those of dissolved sulfates in geothermal brines of which waters and sulfur species are of meteoric and volcanic origin, respectively.

Assuming attainment of isotopic equilibrium between precipitating barite and ore fluids, $\delta^{18} \mathrm{O}$ values for the ore fluids of Sambo are calculated to be -2.1 to $+0.9 \%$, using the isotopic fractionation factor by Kusakabe and Robinson (1977). The calculated results are listed in Table 2 .

Quartz has $\delta^{18} \mathrm{O}$ values ranging from +4.6 to $+8.6 \%$, which differ by $4 \%$ from barite $\delta^{18} \mathrm{O}$. The calculated $\delta^{18} \mathrm{O}$ values of ore fluids in equilibrium with the quartz range from -4.2 to $-1.3 \%$, using the quartz-water fractionation factor by Matsuhisa et al. (1979, Table 2). The fluid $\delta^{18} \mathrm{O}$ values calculated from $\delta^{18} \mathrm{O}_{\mathrm{Qtz}}$ are slightly lower than those estimated from the $\delta^{18} \mathrm{O}_{\mathrm{Bar}}$. The difference can be interpreted to indicate that barite and quartz were possibly deposited from different evolutional stages of ore fluids. Quartz may have precipitated later than barite from a fluid having lower $\delta^{18} \mathrm{O}$ due to increased mixing of meteoric water.

It appears that the ore fluids were gradually depleted in ${ }^{18} \mathrm{O}$ with time in the evolution of the ore fluids as shown in Table 2; stage I $\left(\delta^{18} \mathrm{O}_{\text {fluid }}=-1.3 \sim-1.7 \%\right.$ ), stage II $(-1.3 \sim-3.0 \%$ and stage III (-3.0 - - 4.2\%o). This is consistent with a decrease in the salinity of fluid inclusions toward 
latest stage as reported by So et al. (1984).

Based on the $\delta^{18} \mathrm{O}$ values of quartz and barite, the ore fluid of the Sambo mineral deposits is likely to have originated from a magmatic hydrothermal fluid mixed with meteoric water, the contribution of which increased toward later veinforming stages.

\section{CONCLUSIONS}

Sulfide and sulfate minerals show a remarkably homogeneous sulfur isotopic composition regardless of time and space in mineralization. This implies that no significant change of physico-chemical conditions occurred in the ore fluids during the vein forming stages. Isotopic temperatures of the ore fluids estimated using sulfide-sulfate mineral pairs are from 210 to $290^{\circ} \mathrm{C}$ during the main mineralization stage. These temperatures are in good agreement with homogenization temperatures of fluid inclusions in quartz, suggesting the isotopic equilibria between sulfides and sulfate.

The $\delta^{18} \mathrm{O}$ values estimated for the ore fluids suggest that influx of meteoric water into the magmatic hydrothermal system at Sambo increased toward later stages of the mineralization.

Acknowledgments-This manuscript has been improved considerably by two Geochemical Journal reviewers. Special thanks go to Dr. Y. Matsuhisa, Executive Editor of Geochemical Journal, for critical and valuable comments. Fieldwork, sample preparation and analytical works were supported in part by a research fund of the Center for Mineral Resources Research sponsored by the Korea Science and Engineering Foundation and the Korea Research Foundation and Ewha Womans University. Thanks are extended to Park Jaekyong and Lee Jinsoo who assisted us in fieldwork, in drafting and preparing this paper.

\section{REFERENCES}

Clayton, R. N. and Mayeda, T. K. (1963) The use of bromine pentafluoride in the extraction of oxygen from oxide and silicates for isotope analysis. Geochim. Cosmochim. Acta 27, 43-52.

Jwa, Y. J. (1989) Vein formation and mineralization of the Sambo Pb-Zn-Ba deposit, South Korea. Mining Geol. 39, 383-392.
Kim, K. H. and Nakai, N. (1980) Sulfur isotope composition and isotopic temperatures of some base metal ore deposits, South Korea. Geol. Soc. Korea Jour. 16, 124-134 (in Korean with English abstract).

Kusakabe, M. and Robinson, B. W. (1977) Oxygen and sulfur isotope equilibria in the $\mathrm{BaSO}_{4}-\mathrm{HSO}_{4}{ }^{-}-\mathrm{H}_{2} \mathrm{O}$ system from 110 to $350^{\circ} \mathrm{C}$ and applications. Geochim. Cosmochim. Acta 41, 1033-1040.

Longinelli, A. and Craig, H. (1967) Oxygen-18 variations in sulfate ions in sea water and saline lake. Science 156, 56-59.

Matsuhisa, Y., Goldsmith, J. R. and Clayton, R. N. (1979) Oxygen isotopic fractionation in the system quartz-albite-anorthite-water. Geochim. Cosmochim. Acta 43, 1131-1140.

Mizutani, Y. (1971) An improvement in the carbonreduction method for the oxygen isotopic analysis of sulfates. Geochem. J. 5, 69-77.

Mizutani, Y. (1972) Isotopic composition and underground temperature of the Otake geothermal water, Kyushu, Japan. Geochem. J. 5, 69-77.

Nuelle, L. M. and Shelton, K. L. (1986) Geologic and geochemical evidence of possible bedded barite deposits in Devonian rocks of the Valley and Ridge Province, Appalachian Mountains. Econ. Geol. 81, 1408-1430.

Ohmoto, H. and Lasaga, A. C. (1982) Kinetics of reactions between aqueous sulfates and sulfides in hydrothermal system. Geochim. Cosmochim. Acta 46, 1727-1745.

Ohmoto, H. and Rye, R. O. (1979) Isotopes of sulfur and carbon. Geochemistry of Hydrothermal Ore Deposits (Barnes, H. L., ed.), 509-567, John Wiley, New York.

Park, N. Y. and Park, K. H. (1980) The fluid inclusions in the sphalerite from the Sambo lead-zinc deposits. Geoscience Mineral Resources 9, 65-71 (in Korean with English abstract).

Rafter, T. A. (1957) Sulphur isotopic variation in nature, part 1. The preparation of sulphur dioxide for mass spectrometer examination. N. Z. J. Sci. Tech. B. 38, 849 .

Rafter, T. A. and Mizutani, Y. (1967) Oxygen isotopic composition of sulphates. Part 2. Preliminary results on oxygen isotopic variation in sulphates and the relationship to their environment and to their $\delta^{34} \mathrm{~S}$ values. N. Z. J. Sci. 10, 816-840.

Robinson, B. W. and Kusakabe, M. (1975) Quantitative preparation of sulfur dioxide for ${ }^{34} \mathrm{~S} /{ }^{32} \mathrm{~S}$ analyses from sulfides by combustion with cuprous oxide. Anal. Chim. 47, 1179-1181.

Sakai, H. (1977) Sulfate-water isotope thermometry applied to geothermal systems. Geothermics 5, 67-74. Sakai, H. and Dickson, F. W. (1978) Experimental de- 
termination of the rate and equilibrium fractionation factors of sulfur isotope exchange between sulfate and sulfide in slightly acid solutions at $300^{\circ} \mathrm{C}$ and 1000 bars. Earth Planet. Sci. Lett. 39, 151-161.

Sakai, H., Osaki, S. and Tsukagishi, M. (1970) Sulfur and oxygen isotopic geochemistry of sulfate in the black ore deposits of Japan. Geochem. J. 4, 27-39.

So, C. S., Park, M. E., Shelton, K. L. and Seidemann, D. E. (1984) Geology and geochemistry of the Sambo
$\mathrm{Pb}-\mathrm{Zn}$ deposits, Republic of Korea. Econ. Geol. 79, 656-670.

Solomon, M., Rafter, T. A. and Jensen, M. L. (1969) Isotope studies on the Rosebery, Mount Farrell and Mount Lyell ores, Tasmania. Mineral. Deposita 4, 172-199.

Thode, H. G., Monster, J. and Dunford, H. B. (1961) Sulphur isotope geochemistry. Geochim. Cosmochim. Acta 25, 159-174. 